\title{
Neuropathological analysis of the brains of fifty-two patients with COVID-19
}

\author{
Teresa Wierzba-Bobrowicz ${ }^{1}$, Paweł Krajewski², Sylwia Tarka², Albert Acewicz ${ }^{1}$, Paulina Felczak ${ }^{1}$, Tomasz Stępień ${ }^{1}$, \\ Maciej P. Golan ${ }^{3}$, Michat Grzegorczyk ${ }^{4}$ \\ ${ }^{1}$ Department of Neuropathology, Institute of Psychiatry and Neurology, Warsaw, Poland, ${ }^{2}$ Department of Forensic Medicine, Medical \\ University of Warsaw, Warsaw, Poland, ${ }^{3}$ Laboratory of Molecular Oncology and Innovative Therapies, Military Institute of Medicine, \\ Warsaw, Poland, ${ }^{4}$ Department of Anatomy, Medical University of Warsaw, Warsaw, Poland
}

\begin{abstract}
Coronavirus disease 2019 (COVID-19) poses a global challenge to healthcare and society in the early $21^{\text {st }}$ century. We report neuropathological changes in 52 patients aged between 22 years and 88 years (median 58 years) who were infected with the CoV-2 coronavirus. Patients died under various circumstances and had various pre-existing diseases. The inclusion criteria for this study were: positive result for the nasopharyngeal swab for SARS-CoV-2 RNA, diagnosis of pneumonia of SARS-COV-2 or nucleoproteins of SARS-COV-2 in pulmonary tissue confirmed by immunohistochemical methods (IHC). Samples from all brain structures and lung specimens were taken for histopathological examinations. Brain and pulmonary samples were stained typically with histological and immunohistochemical methods and small tissue fragments were examined with the transmission electron microscope (TEM). The light and electron microscopy examination confirmed the numerous neuropathological changes in the brains of the patients infected with the CoV-2. Many of these changes were caused by pre-existing diseases of patients and/or by necessary treatment. However, vascular lesions and the inflammatory process seem to be characteristic of the CoV-2 infection. In all of the structures of 52 brains of patients, damage of the vessel walls and morphological feature of the damage to the blood-brain barrier were observed. Lymphocytic and microglial infiltrates, both perivascular and diffuse, were also observed. Hence, the brain changes due to COVID-19 infection, could be called COVID-19 cerebral angiopathy with diffuse inflammation.
\end{abstract}

Key words: COVID-19, CoV-2, SARS-CoV-2, neuropathology, ultrastructure.

\section{Introduction}

Severe acute respiratory syndrome coronavirus 2 (SARS-CoV-2) is a non-segmented positive-sense RNA virus belonging to the Coronaviridae family, first identified in Wuhan, China in December 2019 [10]. It is responsible for the ongoing global pandemic of coronavirus disease 19 (COVID-19), with recurrent waves in most countries, more than 130 million peo- ple infected and about three million deaths worldwide. Infections with SARS-CoV-2 primarily lead to the respiratory tract infection and its sequelae frequently dominate the clinical course [30]. Although, it was found that up to $36 \%$ of COVID-19 patients presented with nervous system symptoms, ranging from anosmia, dysgeusia, headache, dizziness, impaired consciousness, anxiety, agitation, to more 
severe acute ischemic stroke, microhaemorrhages, meningoencephalitis, haemorrhagic posterior reversible encephalopathy syndrome (PRES), acute disseminated encephalomyelitis (ADEM), diffuse leukoencephalopathy or Guillain-Barré syndrome [6,12].

There is a growing body of reports describing pathological findings in the central nervous system (CNS) of patients with the SARS-CoV-2 infection. Although, most of them are autopsy case reports or case series with less than 50 subjects. In the systemic review of Pajo et al. [22] who analysed 14 publications with a total of 146 COVID-19 cases which underwent brain autopsy, the striking pathologic changes included diffuse oedema (17.1\%), gliosis with diffuse activation of microglia and astrocytes (35.6\%), infarctions involving cortical and subcortical areas of the brain (2.7\%), intracranial bleed (subarachnoid haemorrhage and punctate haemorrhages) (12.4\%), arteriosclerosis (29.5\%), hypoxic-ischemic injury (28.1\%), and signs of inflammation (35.6\%). Interestingly, $47.9 \%$ of cases tested negative in SARS-CoV-2 immunohistochemistry, $15.1 \%$ were positive and the rest was unreported (37\%). Similarly, in a more recent review of Sieracka et al. [24], which summarizes 22 publications (more than 300 cases with brain autopsy), CNS pathology includes most frequently features of non-specific neuroinflammation with microglial activation and lymphoid infiltrations, ischemic/hypoxic encephalopathy, astrogliosis, acute cerebrovascular disease, secondary myelin injury, and microthrombi with some brains remaining unaffected or showing only non-specific changes.

Mechanisms responsible for the CNS invasion and brain damage of the SARS-CoV-2 are still unclear. Major hypotheses suggest that the virus can invade the CNS through neuronal-axonal transport or through the bloodstream, and angiotensin-converting enzyme 2 (ACE2) receptors play a crucial role as an entry route [5]. SARS-CoV-2 presents high affinity for the ACE2 receptor, which might lead to virion attachment to the cerebral capillary walls and distortion of the blood-brain barrier $[1,2]$. On the other hand, glial cells and neurons express ACE2 receptors, and attachment of the virus to the receptor could contribute to its neurotropism $[1,2]$. The olfactory tract seems to be the principal entry route to the CNS in the initial phases of the SARS-CoV-2 infection $[5,20]$. Thus, neurotropism and direct invasion of SARS-CoV-2 into the CNS, together with brain hypoxia caused by systemic respiratory failure and indirect mechanisms mediated by the macrophages and T-lymphocytes and cytokine storm induced by systemic SARS-CoV-2 inflammation seem to be major mechanisms that may contribute to a spectrum of neuropathological manifestations $[5,12,22]$. Interestingly, hypotheses emerge that SARS-CoV-2 can cause or accelerate neurodegenerative diseases, i.e., Parkinson's disease, CreutzfeldtJakob disease $[9,25,32]$.

In the present study we describe pathological changes in the brains of 52 patients with COVID-19.

\section{Material and methods}

The 52 patients with COVID-19 derived from the First Polish Brain Bank at the Institute of Psychiatry and Neurology, Warsaw, Poland. Criteria for inclusion in this study were: a positive result for the nasopharyngeal swab for SARS-CoV-2 RNA, diagnosis of pneumonia of SARS-CoV-2 and/or presence of SARS-CoV-2 nucleoprotein in pulmonary tissue was confirmed by immunohistochemical (IHC). Characteristics of cases are included in Table I. All brains were fixed in buffered $4 \%$ formaldehyde. Brain autopsies were performed in the Department of Neuropathology, Institute of Psychiatry and Neurology in Warsaw, Poland.

For neuropathological examinations, samples were taken from the olfactory bulb, frontal, parietal, temporal and occipital lobes, basal ganglia, midbrain, pons, medulla oblongata and cerebellum for each case. Lung specimens were also collected for examination. Tissue samples were processed and stained with haematoxylin and eosin and methods: Klüver-Barrera, Bielschowsky, using standard procedures. For microscopical examination, randomly selected sections of lungs and brain were analysed by immunohistochemical method with CoV-2 (Invitrogen, Ma1-7404, $1: 100$ ) but fragments from human brain were analysed by IHC with antibodies against GFAP (Bio-Rad, MCA4733GA, $1: 300$ ), CD68 (Cell Marque $1: 250$ ), ACE2 (Invitrogen, MA5-31395, 1 : 100), CD45 (LeiCa, NCL-L-UCHL1, 1 : 500), CD20 (NCL-L-CD20-L26, $1:$ 100), LCA (Dako, 8B11-PD7/26, $1: 75$ ), PrP (Cayman Chemical Company, 189710, $1: 250)$, TDP43 (Invitrogen, MA5-27828, $1: 1000$ ), $\alpha$-SYN (Leica, NCL-L-ASYN, 1 : 30), $\beta$-amyloid (DAKO, 6F/3D8, $1: 75$ ), Ubiquitin (Invitrogen, PAS-16829, $1: 90$ ), and HLADR (Invitrogen, PA5-22279, $1:$ 1000). Sections were incubated with antibodies and a chromogen, and 
Table I. Clinical description of study subjects

\begin{tabular}{|c|c|c|c|c|c|}
\hline $\begin{array}{l}\text { Case } \\
\text { No. }\end{array}$ & Sex & $\begin{array}{l}\text { Age } \\
\text { (years) }\end{array}$ & $\begin{array}{l}\text { Place } \\
\text { of death }\end{array}$ & $\begin{array}{l}\text { Cause } \\
\text { of death }\end{array}$ & Comorbidities \\
\hline $1^{*}$ & Female & 80 & Hospital & Pneumonia & $\begin{array}{l}\text { CAA, diabetes mellitus type } 2 \text {, dementia, history of stroke, } \\
\text { hypertension, goiter of the thyroid gland, epilepsy, history of limb } \\
\text { vein thrombosis, history of staphylococcal sepsis }\end{array}$ \\
\hline $2^{*}$ & Female & 60 & $\begin{array}{l}\text { Emergency } \\
\text { room }\end{array}$ & Pneumonia & Hypertension, diabetes mellitus type 2 , thyroid nodule \\
\hline 3 & Male & 88 & Home & Pneumonia & Cardiomyopathy \\
\hline 4 & Male & 61 & Hospital & Pneumonia & $\begin{array}{l}\text { History of pulmonary embolism, peptic ulcer disease, } \\
\text { hyperthyroidism, rheumatoid arthritis, history of lobectomy, } \\
\text { hypertension }\end{array}$ \\
\hline $5^{*}$ & Male & 69 & Hospital & Pneumonia & $\begin{array}{l}\text { Diabetes mellitus type 2, schizophrenia, epilepsy, benign prostatic } \\
\text { hyperplasia, history of post-traumatic intracranial haemorrhage, } \\
\text { parkinsonism }\end{array}$ \\
\hline 6 & Male & 72 & Hospital & $\begin{array}{l}\text { Acute } \\
\text { myocardial } \\
\text { infarction, } \\
\text { pneumonia }\end{array}$ & $\begin{array}{l}\text { Chronic heart failure, IHD, history of acute myocardial infarction, } \\
\text { hypertension, dyslipidaemia, obesity, gout, benign prostatic } \\
\text { hyperplasia, history of post-traumatic intracranial haemorrhage, } \\
\text { acute pancreatitis }\end{array}$ \\
\hline 7 & Female & 71 & Hospital & Pneumonia & $\begin{array}{l}\text { Depression, rheumatoid arthritis, renal amyloidosis, osteoporosis, } \\
\text { obesity }\end{array}$ \\
\hline 8 & Male & 23 & Car crash & $\begin{array}{l}\text { Head and chest } \\
\text { trauma }\end{array}$ & Lack of data \\
\hline 9 & Male & 45 & $\begin{array}{l}\text { Emergency } \\
\text { room }\end{array}$ & $\begin{array}{l}\text { Pulmonary } \\
\text { embolism }\end{array}$ & $\begin{array}{l}\text { History of intracranial bleeding, traumatic brain injury, acute } \\
\text { pancreatitis, pneumonia }\end{array}$ \\
\hline 10 & Male & 59 & Hospital & Pneumonia & Urolithiasis, ischemic stroke \\
\hline 11 & Male & 45 & $\begin{array}{l}\text { Emergency } \\
\text { room }\end{array}$ & Pneumonia & Lymphoma \\
\hline 12 & Female & 74 & Hospital & $\begin{array}{c}\text { Burn, } \\
\text { pneumonia }\end{array}$ & Thyroid nodules \\
\hline 13 & Female & 50 & Hospital & Pneumonia & Hypertension, diabetes mellitus type 2 , obesity \\
\hline 14 & Male & 74 & Hospital & Pneumonia & $\begin{array}{l}\text { Benign prostatic hyperplasia, IHD, degenerative disease of the spine, } \\
\text { TIA, CAA }\end{array}$ \\
\hline 15 & Male & 37 & Home & Pneumonia & Hypertension, diabetes mellitus type 2 , obesity \\
\hline 16 & Male & 57 & Home & Pneumonia & $\begin{array}{l}\text { History of stent grafting of ascending aorta aneurysm, } \\
\text { cardiomyopathy }\end{array}$ \\
\hline 17 & Male & 66 & Hospital & $\begin{array}{l}\text { Pneumonia, } \\
\text { intestinal } \\
\text { obstruction }\end{array}$ & Colorectal cancer, benign prostatic hyperplasia \\
\hline 18 & Male & 52 & Hospital & $\begin{array}{l}\text { Suicide } \\
\text { (abdomen stab } \\
\text { wound) }\end{array}$ & $\begin{array}{l}\text { History of lobectomy due to recurrent lung abscess and pleural } \\
\text { empyema }\end{array}$ \\
\hline 19 & Male & 56 & $\begin{array}{l}\text { Emergency } \\
\text { room }\end{array}$ & Pneumonia & Cardiomyopathy \\
\hline 20 & Male & 61 & Hospital & Pneumonia & $\begin{array}{l}\text { Diabetes mellitus type 2, nicotine dependence, post-traumatic } \\
\text { intracranial bleeding }\end{array}$ \\
\hline 21 & Male & 62 & Hospital & $\begin{array}{c}\text { Ischemic stroke, } \\
\text { pneumonia }\end{array}$ & $\begin{array}{l}\text { IHD, history of CABG, acute myocardial infarction, implantable } \\
\text { cardioverter defibrillator, diabetes mellitus type 2, chronic renal failure, } \\
\text { dyslipidaemia, hypothyroidism, hypertension, chronic heart failure }\end{array}$ \\
\hline 22 & Female & 66 & $\begin{array}{l}\text { Emergency } \\
\text { room }\end{array}$ & Pneumonia & Obesity, hypertension, diabetes mellitus type 2 \\
\hline 23 & Male & 75 & $\begin{array}{l}\text { Emergency } \\
\text { room }\end{array}$ & $\begin{array}{l}\text { Pneumonia, } \\
\text { alcohol withdrawal } \\
\text { syndrome }\end{array}$ & $\begin{array}{l}\text { Alcohol dependence, diabetes mellitus type } 2 \text {, benign prostatic } \\
\text { hyperplasia, hypothyroidism }\end{array}$ \\
\hline
\end{tabular}


Table I. Cont.

\begin{tabular}{|c|c|c|c|c|c|}
\hline $\begin{array}{l}\text { Case } \\
\text { No. }\end{array}$ & Sex & $\begin{array}{l}\text { Age } \\
\text { (years) }\end{array}$ & $\begin{array}{l}\text { Place } \\
\text { of death }\end{array}$ & $\begin{array}{l}\text { Cause } \\
\text { of death }\end{array}$ & Comorbidities \\
\hline 24 & Male & 60 & $\begin{array}{l}\text { Emergency } \\
\text { room }\end{array}$ & Pneumonia & Cachexy, malnutrition, CAA \\
\hline 25 & Female & 71 & Hospital & $\begin{array}{l}\text { Pneumonia, } \\
\text { acute myocardial } \\
\text { infarction }\end{array}$ & $\begin{array}{l}\text { IHD, urinary bladder cancer, history of bladder resection, } \\
\text { hypertension, diabetes mellitus type } 2\end{array}$ \\
\hline 26 & Male & 63 & $\begin{array}{l}\text { Emergency } \\
\text { room }\end{array}$ & Pneumonia & Ischemic heart disease, diabetes mellitus type 2 , hypertension \\
\hline 27 & Female & 56 & Hospital & Pneumonia & Asthma, hypertension, depression, urinary bladder cancer \\
\hline 28 & Female & 59 & Home & $\begin{array}{l}\text { Pneumonia, } \\
\text { acute myocardial } \\
\text { infarction }\end{array}$ & Obesity, CAA \\
\hline 29 & female & 66 & ICU & $\begin{array}{l}\text { Suicide (drug } \\
\text { poisoning) }\end{array}$ & Hypertension, diabetes mellitus type 2, obesity, pneumonia \\
\hline 30 & Male & 54 & Street & Choking & IHD, alcohol dependence, pneumonia \\
\hline 31 & Male & 78 & Hospital & $\begin{array}{l}\text { Acute renal } \\
\text { failure, } \\
\text { subarachnoid } \\
\text { haemorrhage }\end{array}$ & Prostate cancer, obstructive uropathy, pneumonia \\
\hline 32 & Female & 70 & Home & $\begin{array}{l}\text { Acute myocardial } \\
\text { infarction, } \\
\text { pneumonia }\end{array}$ & IHD, CAA, parkinsonism \\
\hline 33 & Female & 36 & ICU & $\begin{array}{l}\text { Acute } \\
\text { peritonitis, } \\
\text { pneumonia }\end{array}$ & Acute pancreatitis, chest and abdomen trauma \\
\hline 34 & Male & 35 & Home & Pneumonia & Atrial fibrillation, cardiomyopathy, scoliosis \\
\hline 35 & Male & 72 & ICU & Pneumonia & $\begin{array}{l}\text { Hypertension, schizophrenia, urolithiasis, benign prostatic } \\
\text { hyperplasia }\end{array}$ \\
\hline 36 & Male & 51 & Home & $\begin{array}{l}\text { Suicide (cutting } \\
\text { the wrist arteries) }\end{array}$ & History of appendectomy, history of craniectomy, pneumonia \\
\hline 37 & Male & 72 & Hospital & Pneumonia & $\begin{array}{l}\text { Chronic kidney failure, kidney cystic disease, cardiomyopathy, } \\
\text { hypertension, history of acute myocardial infarction, IHD, celiac } \\
\text { disease, peptic ulcer disease, rectal varices, albinism, benign } \\
\text { prostatic hyperplasia }\end{array}$ \\
\hline 38 & Female & 60 & Hospital & Pneumonia & $\begin{array}{l}\text { Lung cancer, depression, asthma, emphysema, sinusitis, IHD, history } \\
\text { of acute myocardial infarction, atrial fibrillation, hypertension, } \\
\text { mitral valve prolapse, epilepsy, hydrocephalus, cachexy, chronic } \\
\text { kidney disease, hypothyroidism }\end{array}$ \\
\hline 39 & Male & 71 & Hospital & $\begin{array}{c}\text { Suicide } \\
\text { (suffocation) }\end{array}$ & Depression, hypertension, pneumonia \\
\hline 40 & Male & 33 & Hospital & $\begin{array}{l}\text { Sepsis, } \\
\text { pneumonia, } \\
\text { meningitis }\end{array}$ & $\begin{array}{l}\text { Traumatic brain injury, post-traumatic intracranial bleeding, post- } \\
\text { traumatic hydrocephalus, ventricular-peritoneal valve implantation }\end{array}$ \\
\hline 41 & Male & 22 & Home & $\begin{array}{l}\text { Pneumonia, } \\
\text { acute myocardial } \\
\text { infarction }\end{array}$ & No comorbidities \\
\hline 42 & Male & 28 & Hospital & Brain oedema & Pneumonia, hyponatremia \\
\hline 43 & Male & 29 & Home & Pneumonia & No comorbidities \\
\hline 44 & Female & 69 & Hospital & $\begin{array}{l}\text { Pneumonia, } \\
\text { sepsis }\end{array}$ & $\begin{array}{l}\text { Lung cancer, depression, polyneuropathy, trigeminal neuralgia, } \\
\text { thyroid nodules, degenerative disease of the spine }\end{array}$ \\
\hline 45 & Male & 37 & Workplace & Pneumonia & Obesity \\
\hline 46 & Female & 67 & Hospital & Pneumonia & $\begin{array}{l}\text { Diabetes mellitus type } 2 \text {, diabetic retinopathy, hypertension, } \\
\text { dyslipidaemia, obesity, history of cholecystectomy }\end{array}$ \\
\hline 47 & Male & 62 & Home & Pneumonia & Chronic limb ischemia, IHD, history of acute myocardial infarction \\
\hline
\end{tabular}


Table I. Cont.

\begin{tabular}{|llcccl|}
\hline $\begin{array}{c}\text { Case } \\
\text { No. }\end{array}$ & Sex & $\begin{array}{c}\text { Age } \\
\text { (years) }\end{array}$ & $\begin{array}{c}\text { Place } \\
\text { of death }\end{array}$ & $\begin{array}{c}\text { Cause } \\
\text { of death }\end{array}$ & Comorbidities \\
\hline 48 & Male & 63 & Home & Pneumonia & Lack of data \\
\hline 49 & Male & 44 & Hospital & Pneumonia & History of spleen removal \\
\hline 50 & Male & 44 & Home & Pneumonia & Obesity \\
\hline 51 & Male & 64 & ICU & Pneumonia & History of fingers amputation \\
\hline 52 & Male & 61 & Home & Pneumonia & Cholecystolithiasis \\
\hline
\end{tabular}

${ }^{*}$ Case with electron microscopy examination. CAA - cerebral amyloid angiopathy, ICU -intensive care unit, IHD - ischemic heart disease, TIA - transient ischemic attack, $C A B G$ - coronary artery bypass grafting

counterstained with haematoxylin by conventional immunohistochemical manual procedures.

The ultrastructural studies were conducted on material from autopsy cases of three patients with COVID-19 of 69 (No. 5, taken on 72 hours after death), 80 (No. 1) and 60 (No. 2) years old respectively. Biological samples were collected from brain and lung lobe tissues. Small blood vessels in the brain and lungs were examined. For electron microscopic evaluation, most of the small fragments of tissues were fixed in $2.5 \%$ glutaraldehyde solution in cacodylate buffer $\mathrm{pH}$ 7.4. Other fragments of tissues were taken from paraffin blocks and after deparaffinizing with xylene and washing in water they also were fixed in $2.5 \%$ glutaraldehyde solution in cacodylate buffer $\mathrm{pH}$ 7.4. Then all the samples were postfixed in the $1 \%$ osmium tetroxide solution in the same buffer. After dehydration in a graded ethanol series and propylene oxide, specimens were embedded in Spurr resin. Semithin sections were stained with toluidine blue to choose appropriate areas. Ultrathin sections were contrasted with uranyl acetate and lead citrate. The sections were examined and photographed with transmission electron microscope (TEM), JEOL model 140 at the Nencki Institute of Experimental Biology, Polish Academy of Sciences in Warsaw, Poland.

\section{Results}

The median age of the 52 patients was 58 years (range 22-88), 15 (29\%) patients were women and 37 (71\%) were men. 48 (92\%) had relevant pre-existing medical conditions, among them 25 patients (48\%) had relevant cardiorespiratory problems, and 15 (29\%) had pre-existing neurological and/or psychiatric diseases. 36 patients died in hospital (69\%) and 13 (25\%) patients died at home, the rest, patient number 8 died in a car accident, patient number 30 died on the street and patient number 45 died at the workplace and there were 3 suicides (Table I). Pneumonia was diagnosed in 49 (94\%) patients, of which in 43 (83\%) patients SARS-CoV-2 pneumonia was considered a cause of death. The diagnosis of pneumonia was made either during the lifetime or during a general autopsy. In some cases, IHC or ultrastructural $(M E)$ tests for the presence of the virus (Fig. 1A, 11, 12) were conducted. IHC was use to examined receptors for the angiotensin-converting enzyme-2 (ACE2). In the brain, they were most abundant in the choroid plexus and the arachnoid meningeal (Fig. 1B, C).

In all of the 52 cases, microbleeds/petechial haemorrhages were observed in the subarachnoid space and around the blood vessels of the parenchyma (Figs. 2, 3). The microbleeds/petechial haemorrhages were of varying severity, over all hemispheres of the brain. Hemosiderin deposits were often observed, suggesting previous petechial haemorrhage (Fig. 4C). Distribution and morphology of patchy brain microbleeds and petechial haemorrhages were most prominent in the grey and white matter of the neocortex, but were also found in the brainstem and cerebellum (Fig. 3). Damage to the walls of blood vessels was observed in all examined specimens (Fig. 4). The damage mainly involved arterial vessels and was related to the proliferation and damage of the endothelium, as well as fibrosis and hyalinization of the vessel walls. We also observed diffuse and perivascular proliferation of mononuclear cells in all examined brains (Fig. 5). The greatest intensity of this process was observed in the white matter of the cerebral hemispheres and in the brainstem. The intensity of the process was of various degrees in different cases. In immunohistochemical tests, the diffuse infiltration consisted mainly of microglial cells, while the perivascular infiltration consisted of lymphocytic cells (of which from T lymphocytes) and macrophages (Fig. 6). Additionally, some cells showed IHC reactivity with a class II histocompatibility antigen (HLA DR) (Fig. 6C). Astroglial cell proliferation was also observed in all assessed regions (Fig. 7A). But most of the astroglial cells were damaged. Morphological changes in astrocytes were characterized by fragmentation of 

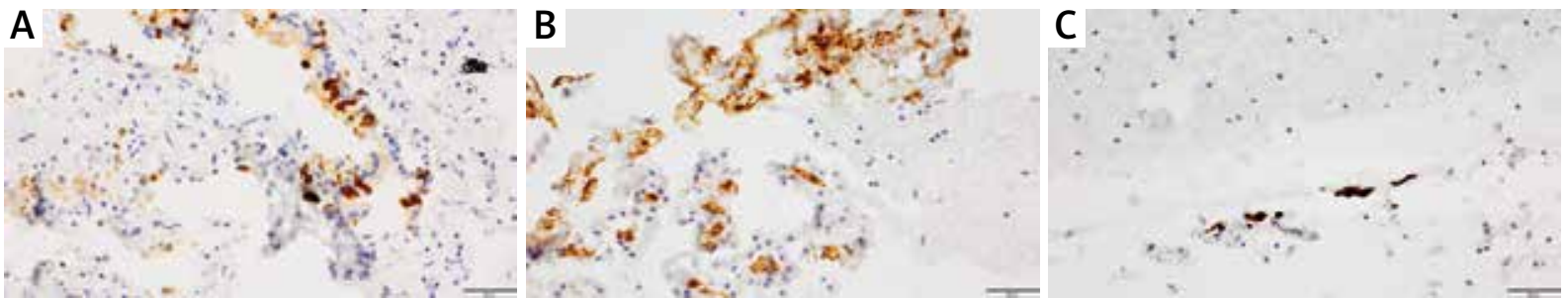

Fig. 1. A) Lung. CoV-2 anti-nucleocapsid protein antibody (IHC, brown) shows a cytoplasmic staining pattern in respiratory epithelial cells, patient No. 3. B) Receptors of angiotensin-converting enzyme 2 (ACE2) immunohistochemistry shows a choroid plexus (brown). Patient No. 31. C) Leptomeninges (brown) immunohistochemical stain of ACE2. Patient No. 51.
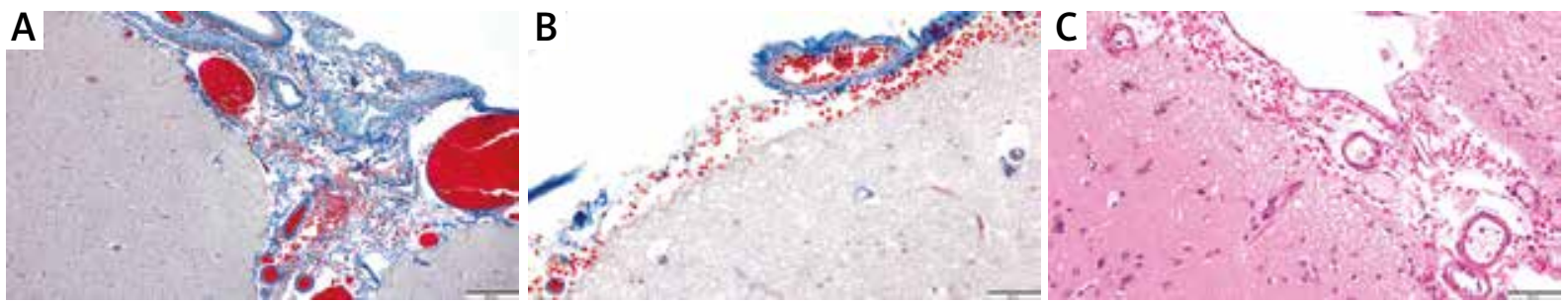

Fig. 2. A) Microbleeds/petechial haemorrhages of varying severity in the arachnoid meninges. Occipital lobe, patient No. 10. Mallory trichrome stain. B) Microbleeds/petechial haemorrhages of varying severity in the arachnoid meninges. Basal ganglia, patient No. 22. Mallory trichrome stain. C) Microbleeds/petechial haemorrhages of varying severity in the arachnoid meninges. Temporal lobe, patient No. 26. H\&E.
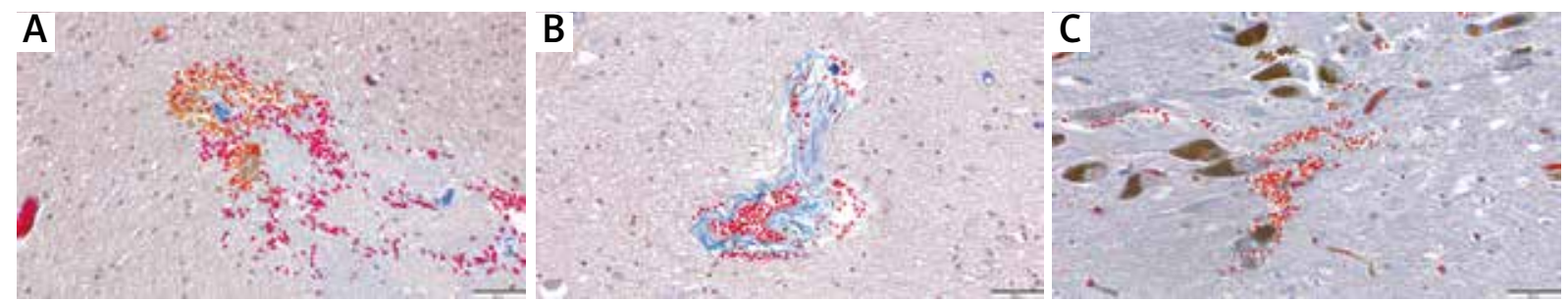

Fig. 3. A) Microbleeds/petechial haemorrhages around the vessels. Mallory trichrome stain. Parietal lobe, white matter. Patient No. 10. B) Microbleeds/petechial haemorrhages around the vessels. Mallory trichrome stain. Basal ganglia. Patient No. 36. C) Microbleeds/petechial haemorrhages around the vessels. Mallory trichrome stain. Mesencephalon. Patient No. 37.
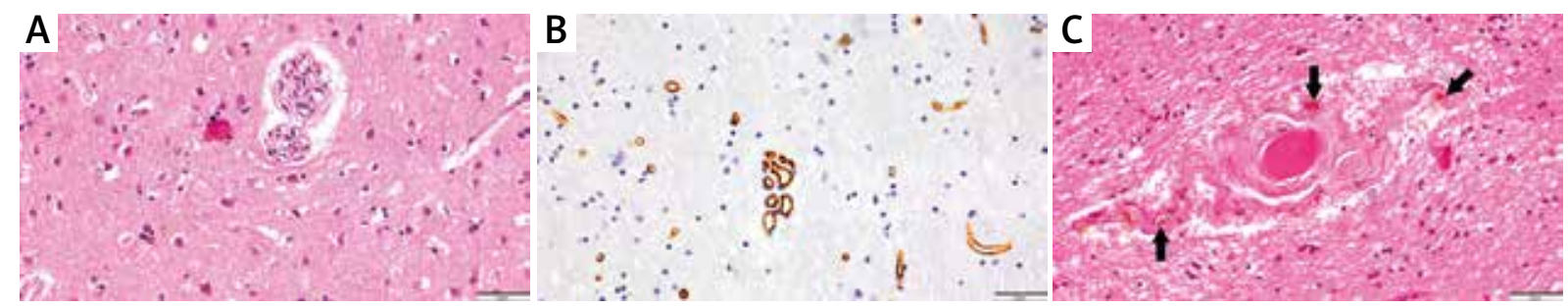

Fig. 4. A) Changes of microvessels. Endothelial proliferation, temporal lobe. Patient No. 13. H\&E. B) Changes of microvessels. Endothelial proliferation, frontal lobe. Patient No. 16. IHC reaction with CD34. C) Changes of microvessels. Fibrosis and hyalinization of the small artery. Haemosiderophages (arrows), frontal lobe. Patient No. 45. H\&E.

the distal processes and swollen cell bodies (clasmatodendrosis). The most damaged cells were the perivascular, submeningeal and subependymal astroglia (Fig. 7B, C).
Apart from the above-mentioned neuropathological changes, ischemic infarctions and haemorrhagic infarctions were observed in three patients (6\%) (Fig. 8). Perivascular or diffuse demyelination was 

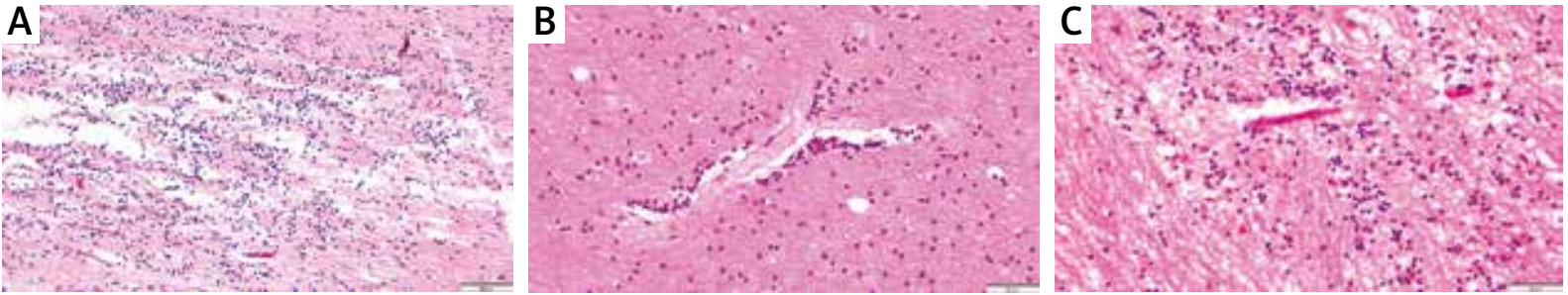

Fig. 5. A) Diffuse and perivascular proliferation of mononuclear cells. Activation of the immune system, H\&E. Diffuse inflammatory infiltrate in the olfactory nerve. Patient No. 45. B) Diffuse and perivascular proliferation of mononuclear cells. Activation of the immune system, H\&E. Perivascular inflammatory infiltration, white matter of frontal lobe. Patient No. 21. C) Diffuse and perivascular proliferation of mononuclear cells. Activation of the immune system, H\&E. Inflammatory process in corpus callosum. Patient No. 7.
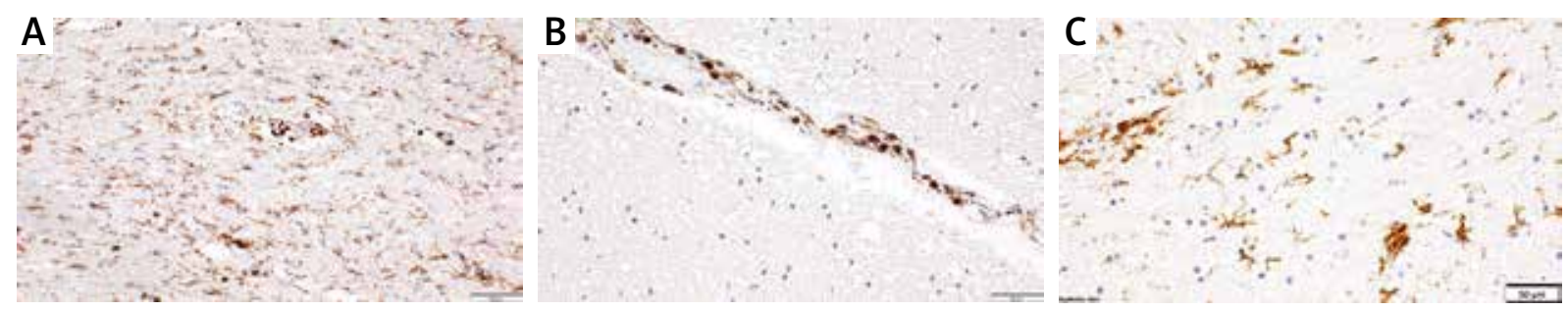

Fig. 6. A) Proliferation of microglia and lymphocytes in the olfactory nerve. Patient No. 36. IHC reaction with antibody LCA. B) Proliferation lymphocytes T. Frontal lobe. Patient No. 17. IHC reaction with CD45RO. C) Activation of the microglial cells. IHC reaction with marker HLA-DR. Patient No. 10. Mesencephalon.
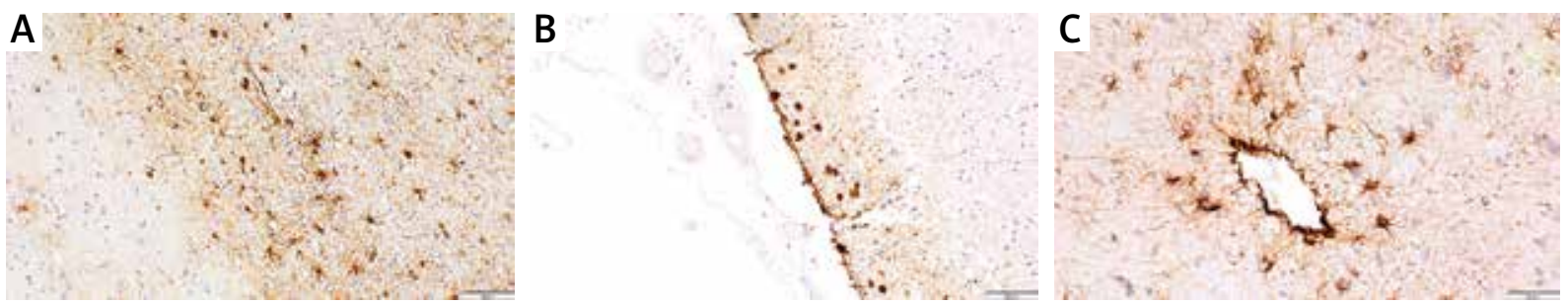

Fig. 7. A) Immunohistochemical reaction for the astroglia (GFAP) reactive astrogliosis with damage of processes of astroglial cells (clasmatodendrosis). Parietal lobe. Patient No. 17. B) Immunohistochemical reaction for the astroglia (GFAP) reactive astrogliosis with damage of processes of astroglial cells (clasmatodendrosis). Submeningeal astroglial cells without processes. Frontal lobe. Patient No. 16. C) Immunohistochemical reaction for the astroglia (GFAP) reactive astrogliosis with damage of processes of astroglial cells (clasmatodendrosis). Damage to the perivascular astroglia. Occipital lobe. Patient No. 35.
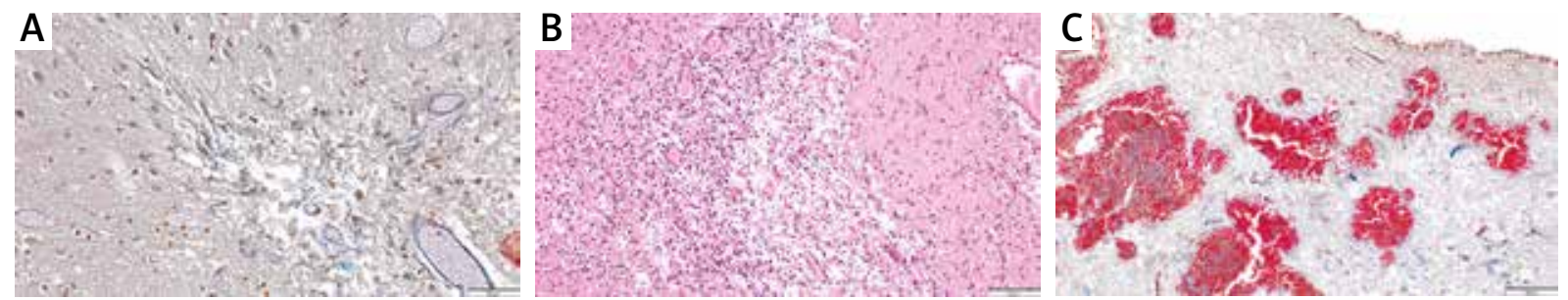

Fig. 8. A) Perivascular lacunar infarction. Temporal lobe. Patient No. 10. Mallory trichrome stain. B) Ischemic infarct. Frontal lobe. Patient No. 21. H\&E. C) Haemorrhagic infarct. Basal ganglia. Patient No. 10. Mallory trichrome stain.

observed in 7 cases (13\%, Fig. 9A, B). In these cases, swelling of the oligodendrocytes was also observed. Lewy bodies were observed in two cases (4\%). They were present in the neurons of substantia nigra of mesencephalon (No. 5, Fig. 9C) or in the neurons of the locus coeruleus of pons (No. 32). Other pro- 

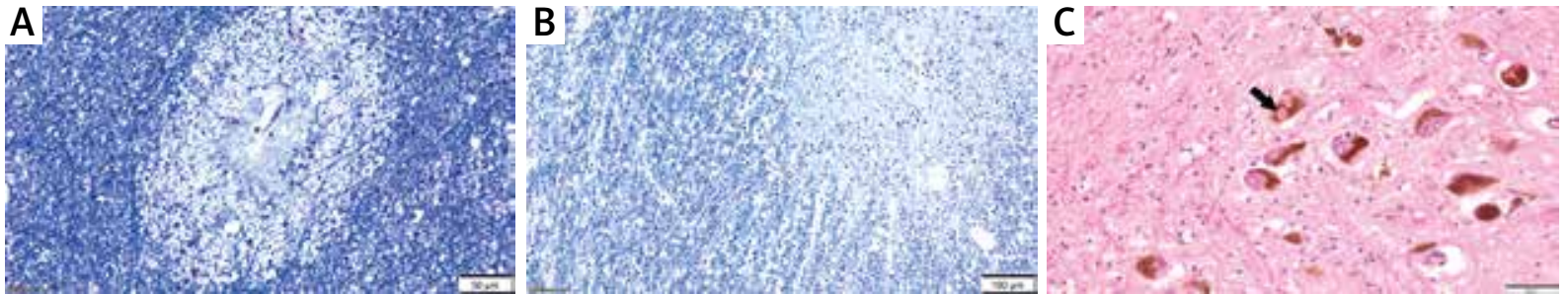

Fig. 9. A) Perivascular demyelination. Occipital lobe. Patient No. 22. Klüver-Barrera. B) Diffuse demyelination. Frontal lobe. Patient No. 10. Klüver-Barrera. C) Lewy's body (arrow). Mesencephalon, substantia nigra. Patient No. 5. H\&E.

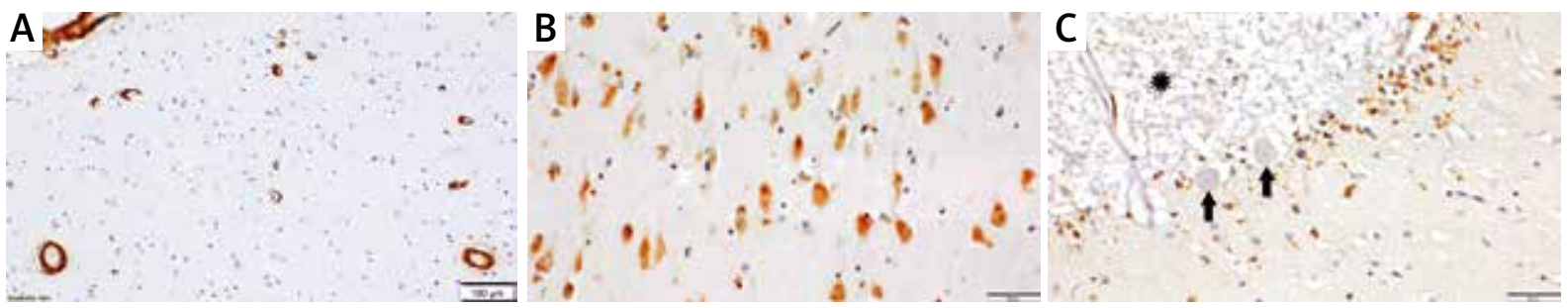

Fig. 10. A) The presence of pathological proteins. $\beta$-amyloid in the vascular walls. Occipital lobe. Patient No. 14. B) The presence of pathological proteins. TDP43 protein visible in the cytoplasm of neurons. Hippocampus. Patient No. 3. C) The presence of pathological proteins. $I H C$ reaction with PrP protein. Positive reaction visible in Bergmann glia in the cerebellum. Loss of neurons in the granular cell layer (asterisk), Purkinje cells (arrows). Patient No. 22.

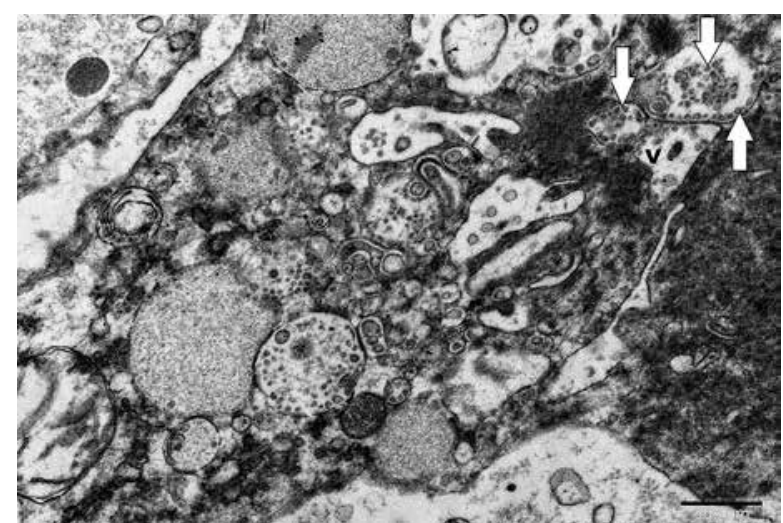

Fig. 11. Lung, type II pneumocyte, viral particles (white arrows) inside vesicles (V). Origin. magn. 40,000x.

teins, including $\alpha$-synuclein, were also immunohistochemically controlled. $\beta$-amyloid was noticed in the vessel walls in 5 cases (10\%, Fig. 10A). Positive IHC response for the TDP43 protein occurred in the cytoplasm of the hippocampal neurons of the temporal lobe in 2 cases (No. 1 and 3, 4\%, Fig. 10B). In the same cases ubiquitin deposits in the cytoplasm of neurons were observed. The PrP prion protein in IHC reaction was observed in the proliferating Bergmann glial cells in the Purkinje cell layer (Fig. 10C). Bergmann glial cell proliferation was observed in cases

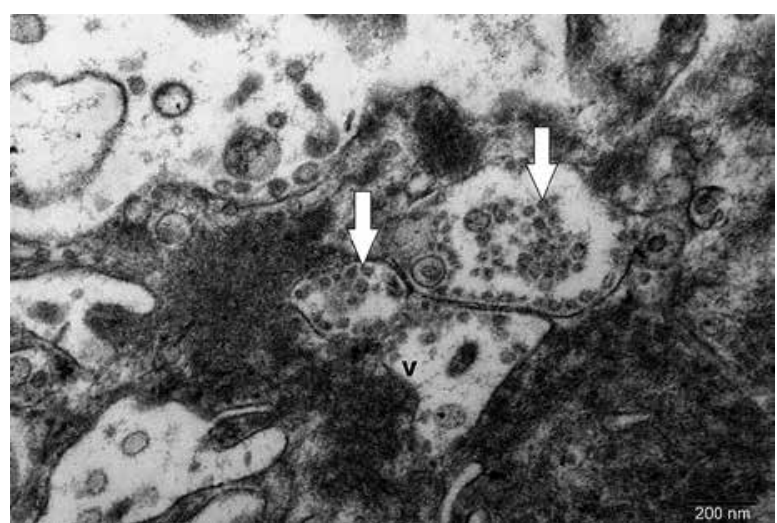

Fig. 12. Viral particles (white arrows) shown in the magnification. $V$ - vesicle. Origin. magn. $80,000 x$.

of atrophy of the granular cell layer (cerebellopathy) (38\% of cases). Ischemic changes in neurons were also observed in many cases.

The ultrastructural examination was performed on selected lung and brain tissue fragments obtained during autopsy of the patients with a positive diagnosis of COVID-19. An accumulation of osmiophilic nucleocapsids in vacuolar vesicles in type II pneumatocytes was observed (Figs. 11, 12). Changes in the morphology of neurons, oligodendrocytes, astrocytes and microglia were found in the 


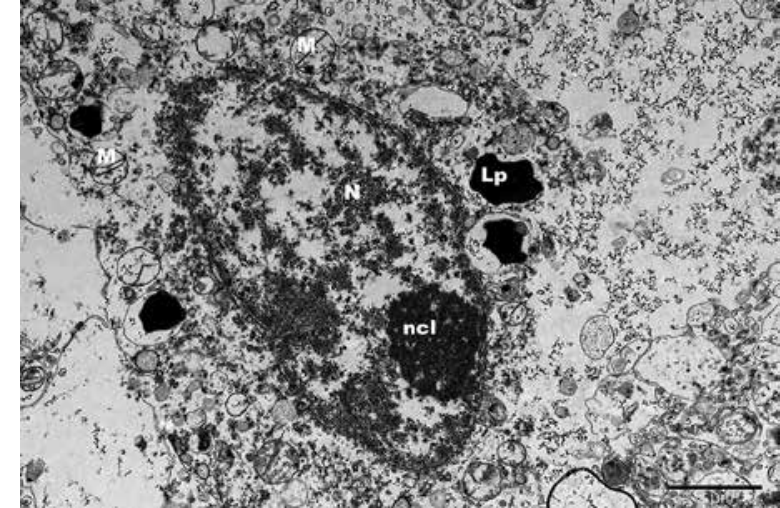

Fig. 13. Neuron in a frontal lobe. Most of the perikaryon of the neuron is occupied by a large, oval nucleus $(\mathrm{N})$ which contains a nucleolus (ncl) and dispersed karyoplasms. The cytoplasm surrounding the nucleus contains swollen mitochondria (M) with damaged cristae, short cisternae of the granular endoplasmic reticulum, free ribosomes and various vesicles. In addition, there are lipofuscin inclusions (LP) in the cytoplasm. Origin. magn. 12,000×.

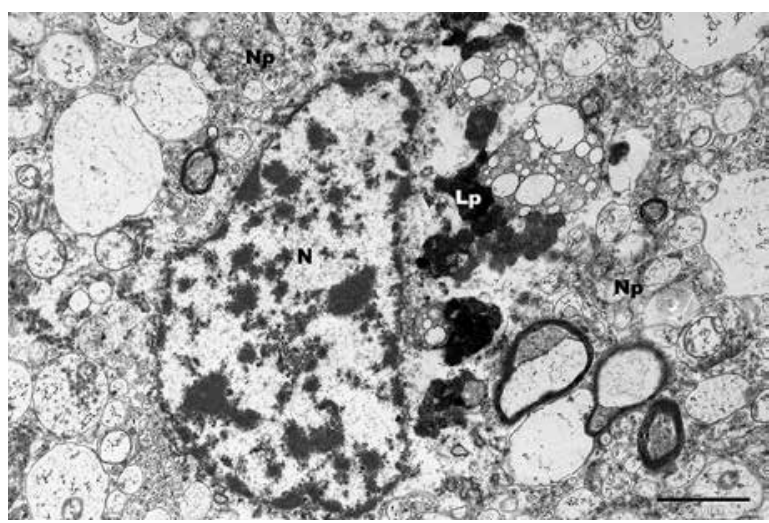

Fig. 15. Astrocyte in a frontal lobe. The nucleus $(\mathrm{N})$ is large, oval with visible condensations of karyoplasm not only beneath the nuclear envelope but also in the middle of the nucleus. Lipofuscin inclusions (Lp) are seen in the cytoplasm near the nucleus. This cell is surrounded by the numerous processes forming the neuropil elements (Np). Origin. magn. 12,000x.

examined fragments of brain tissues (Figs. 13-16) and in the disturbed structure of small blood vessels (Figs. 17-20) under viral infection conditions. The neurons, often with damaged protoplasmic projections, contained swollen mitochondria and few lipofuscin inclusions visible in the cytoplasm (Fig. 13). The oligodendrocytes showed numerous densities

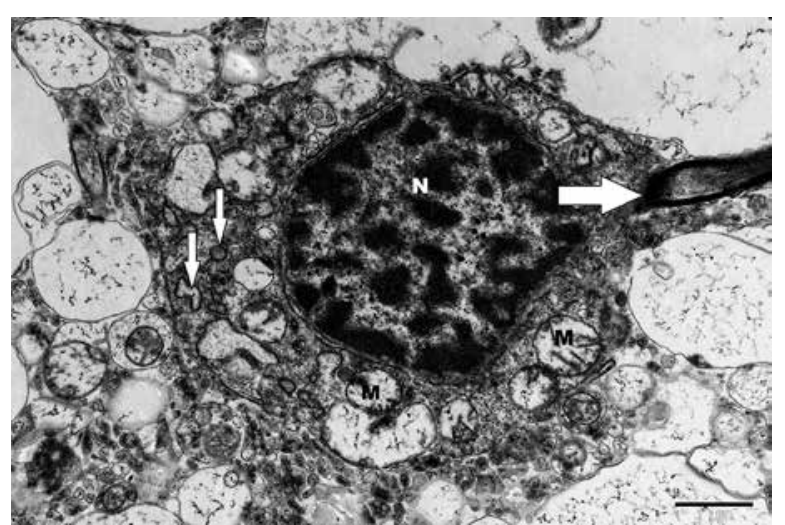

Fig. 14. Oligodendrocyte in a parietal lobe. In the oligodendrocyte the round, dark nucleus (N) with high concentration of chromatin is visible. The dense cytoplasm contains widened short cisternae of granular endoplasmic reticulum (thin arrows), small vesicles, numerous free ribosomes and very swollen mitochondria $(M)$ devoid of cristae. The dark process of an oligodendrocyte (thick arrow). Origin. magn. 20,000x.

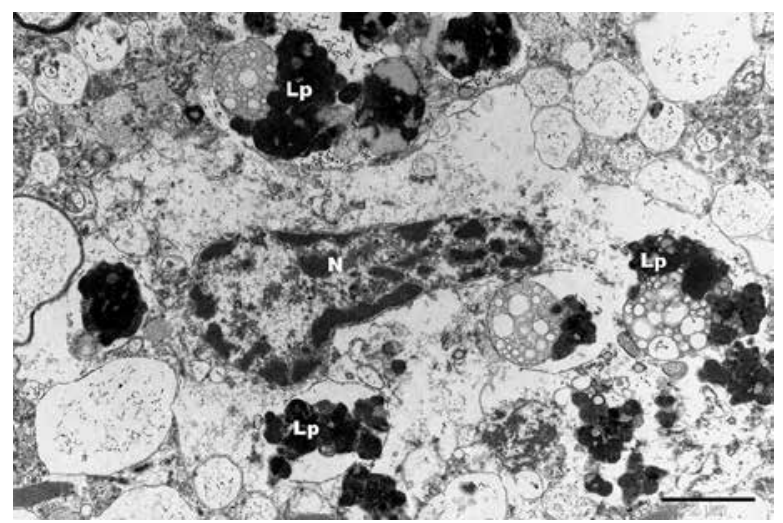

Fig. 16. Microglia in a parietal lobe. The nucleus (N) of this cell is rod-shaped and has unevenly dispersed large clumps of chromatin. The relatively sparse cytoplasm contains fine vesicles and granules. Numerous lipofuscin inclusions (Lp) are visible in the vicinity of the cell. Origin. magn. 12,000×.

of heterochromatin in rounded cell nuclei. The cytoplasm was electron dense and preserved projections were observed in most of these cells (Fig. 14). Astrocytes (Fig. 15), in comparison to the neurons, were surrounded by a dense network of neuropil elements, and in their cytoplasm, near the cell nucleus, osmophilic lipofuscin inclusions were found. 


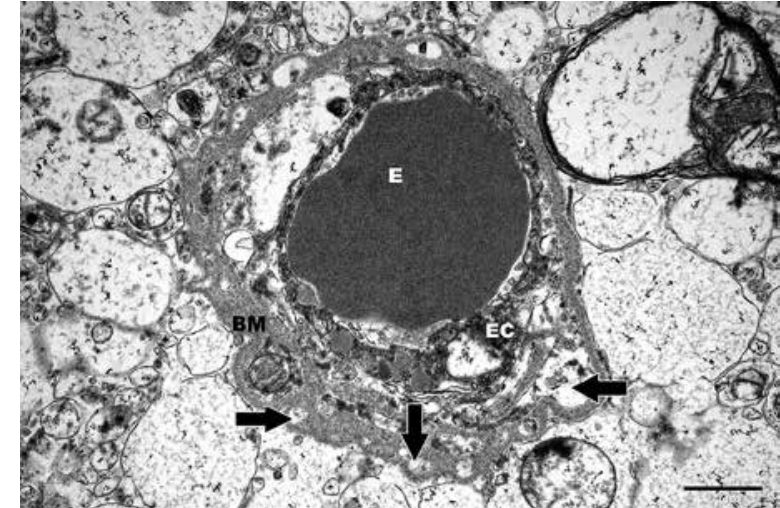

Fig. 17. Capillary in a frontal lobe. The erythrocyte $(E)$ is visible in the capillary lumen. The degenerate endothelial cells (EC) form a dark ring of non-uniform thickness. The basement membrane (BM) is damaged with numerous losses (black arrows) of matrix components. Origin. magn. 20,000x.

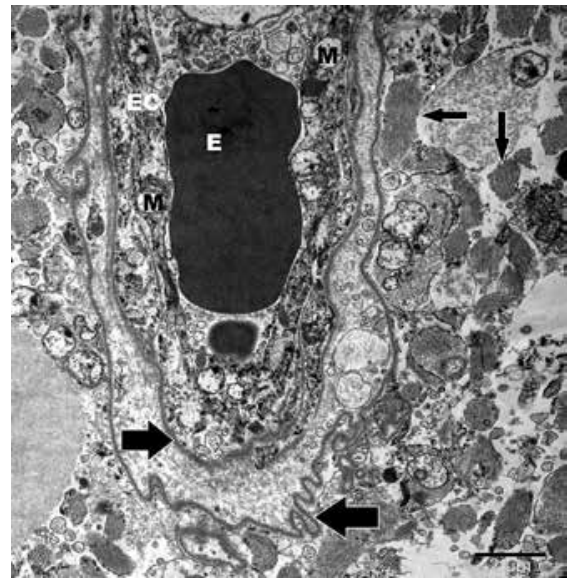

Fig. 19. Olfactory bulb. Capillary. A small blood vessel with erythrocyte (E) in the lumen. Endothelial cells (EC) dilated, degenerated, organelle remains in the cytoplasm, numerous vesicles and granules, swollen mitochondria ( $M$ ) devoid of cristae are visible. Damaged, multi-layered and folded basement membrane (thick arrows). Multiple bundles of fibrils (thin arrows) are visible in the elements of neuropil. Origin. magn. 8,000x.

The greatest amount of lipofuscin deposits was found inside the projections of phagocytic astrocytes and/or macrophages. These inclusions were also observed in the vicinity of the microglia which showed presented rods' shapes (Fig. 16). The most advanced lesions were in the endothelial cells and

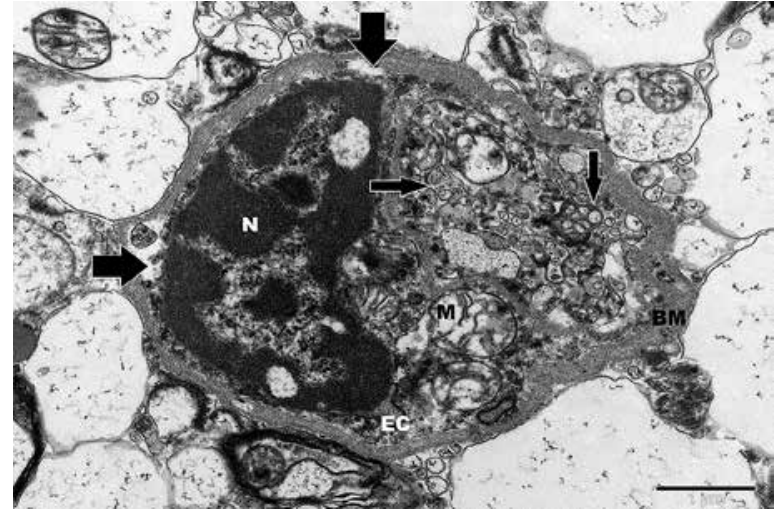

Fig. 18. Capillary in a parietal lobe. Endothelial cells (EC) of the capillary are dilated with degenerative features, filled with numerous vesicles of different electron density (thin arrows). The structure of most organelles has been obliterated, with the exception of the large dark nucleus $(\mathrm{N})$ with chromatin densities; the swollen mitochondria $(M)$ with damaged cristae. Basement membrane (BM) slightly folded and damaged, with local loss of matrix components (thick arrows). Origin. magn. 25,000×.

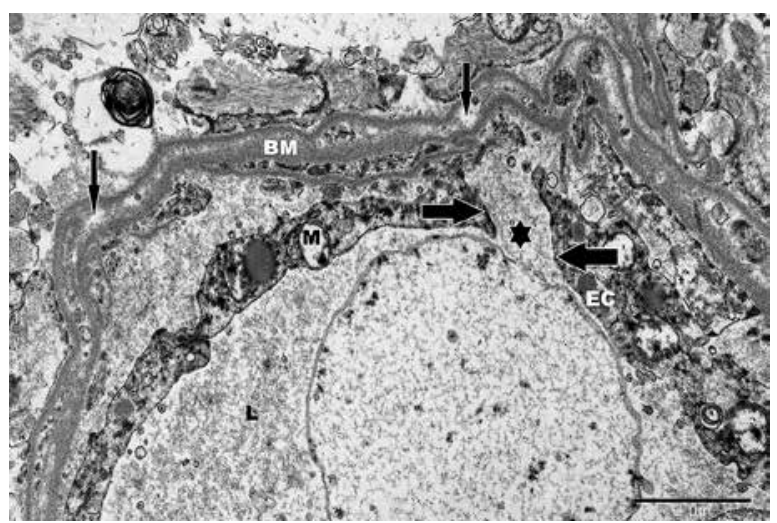

Fig. 20. Olfactory bulb. Fragment of the capillary. Degenerate endothelial cells (EC) with widened (asterisk) tight junction (thick arrows). Vesicles and granules of various sizes, and swollen mitochondria (M) devoid of cristae are visible in the cytoplasm. The basement membrane (BM) is folded, heterogeneous, with loss of matrix components (thin arrows). L - lumen. Origin. magn. 15,000x.

basement membranes of capillaries (Figs. 17-20). The endothelium of most small vessels showed signs of degeneration, was heterogeneous, locally concentrated and in the cytoplasm, it contained vesicles of different size. Composition and osmophilicity as well as mitochondria with remnants of cristae were 
found there (Figs. 17, 18). In endothelial cells, damaged tight junctions were significantly widened (Fig. 20). The basement membranes of most capillaries showed a heterogeneous structure with pronounced local cavities indicative of loss of matrix components (Figs. 17, 18). In capillaries in the olfactory bulb, the basement membranes were thin, multi-layered, and locally folded (Figs. 19, 20).

\section{Discussion}

In our neuropathological diagnosis of brains of 52 patients with coronavirus disease 19 (COVID-19), and with pneumonia (SARS-CoV-2) in 94\% of patients, subarachnoid and perivascular microhaemorrhages and/or petechial haemorrhages predominated. Subarachnoid/cerebral and perivascular microbleeds in brains of SARS-CoV-2 patients could be a consequence of damage to the endothelium and vessel walls, leading to the damage to the bloodbrain barrier and an increase in vascular permeability $[3,18]$. Vascular permeability in COVID-19 patients could be also a consequence of cytokines storm, which induced endothelitis and general vasculopathic changes $[15,18,26]$. Only in one case (Table I, No. 10) a haemorrhagic infarction was observed and in two cases (No. 21 and 26) ischemic infarction. Intracranial haemorrhagic or ischemic infarcts may have occurred as a complication of necessary and/or not sufficient treatment. Ischaemic lesions followed and were likely caused by thromboembolic. Perivascular or diffuse demyelination occurring in several causes was probably caused by ischaemic changes and cerebral oedema caused by vascular disorders [18].

In the brains of patients with COVID-19, we also observed variable degrees of damage of astrocytes. The most common proliferating astroglial cells had short/fragmented processes or they were without processes. As is known, astrocytes are heterogeneous and multifunctional and they are part of the glymphatic system of the brain [14,17]. Damage to the glymphatic system may affect the removal of pathological proteins from the brain, the accumulation of which may be associated with neurodegeneration and the formation of inflammatory response $[14,28]$. Accumulation of $\alpha$-synuclein was observed in two cases of clinical parkinsonism and accumulation of $\beta$-amyloid in the vessel walls was observed in five cases of cerebral amyloid angiopathy CAA (Table I). However, ApoE homo- zygous (e4e4) genotype, predispose to the more severe course of COVID-19 disease [16]. In three men aged between 75 and 88, the protein TDP43 was also observed in the cytoplasm of neurons. TDP-43 plays multiple roles in RNA metabolism including transcription, miRNA processing, RNA transport, nucleocytoplasmic shuttling and splicing, which can lead to dysfunction of both neurons and astroglial cells [7,31]. Cytoplasmic inclusions of TDP-43 in our patients were age-related changes rather than related to COVID-19 infection. The PrP prion protein was observed in the proliferating Bergmann glial cells in cases of atrophy of the granular cell layer (cerebellopathy, in 38\% of our patients). The physiological function of the prion protein remains poorly understood, although it was suggested that PrP may have a normal function in maintenance of long-term memory and regulated cell death [21]. Also, Prion-like domains are critical for virulence in coronavirus disease and the development of therapeutic targets. Tetz and Tetz identified prion-like domains in the ACE2 receptors, interacting with the viral receptor-binding domain of SARS-CoV-2 [13,27].

We also observed diffuse and perivascular proliferation of mononuclear cells in all examined brains. The diffuse infiltration consisted mainly of microglial cells, while the perivascular infiltration consisted of lymphocytic cells and macrophages. We believe that macrophages, and mainly haemosiderophages, phagocytose perivascular blood cells participate in the process of cleaning up necrosis foci. However, most authors believe that the proliferation of lymphocytes and microglia is related to autoimmune processes and changes in the vascular walls, including inflammatory changes $[11,15,18,23,29]$. The authors believed that understanding the role of inflammatory cytokines, chemokines and the immune system could lead to the development of new therapeutic approaches.

Ultrastructural observations showed damage to the blood-brain barrier and energetic disturbances in all of the observed cells of the brain. The endothelial cells of small blood vessels were the most damaged ones. The astroglia and microglia/macrophage cells contained the phagocytic elements. Whereas accumulation of nucleocapsids in vascular vesicles was easier to be observed in type II pneumocytes than in brain structures $[4,8,19]$.

In conclusion, it should be emphasized that many neuropathological changes in the brain are 
caused by pre-existing diseases present in patients infected with the CoV-2 coronavirus and/or by necessary treatment. On the other hand, moderately severe neuropathological changes caused by infection with the CoV-2 virus cover all brain structures with the greatest intensity in the white matter. The lesions include damage to the vessel walls. The changes also included the morphological features of the damage to the blood-brain barrier ("open" tight junctions, clasmodendrosis, damage to elements of the vessel walls). The brain's response to these changes was a diffuse inflammatory process (perivascular and diffuse proliferation of lymphocytes and microglia). Thus, the brain changes induced by SARS-CoV-2 could be called COVID-19 cerebral angiopathy with diffuse inflammation.

\section{Disclosure}

The authors report no conflict of interest.

\section{Acknowledgements}

This work is supported by the "Digital Brain digital collection of the Institute of Psychiatry and Neurology" (Project No. POPC.02.03.01-00.0042/1800). The project "Digital Brain" is co-funded by the European Union and the Polish budget. The authors are very grateful to the First Polish Brain Bank at the Institute of Psychiatry and Neurology, Warsaw, Poland.

(t) uropean Funds Digked pola

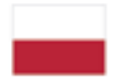

Republic of Poland

\section{European Union}
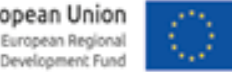

\section{References}

1. Baig AM, Khaleeq A, Ali U, Syeda H. Evidence of the COVID-19 virus targeting the CNS: tissue distribution, host-virus interaction, and proposed neurotropic mechanisms. ACS Chem Neurosci 2020; 11: 995-998.

2. Baig AM, Sanders EC. Potential neuroinvasive pathways of SARS-CoV-2: deciphering the Spectrum of neurological deficit seen in coronavirus disease 2019 (COVID-19). J Med Virol 2020; 92: 1845-1857.

3. Bazzoni G. Endothelial tight junctions: permeable barriers of the vessel wall. Thromb Haemost 2006; 95: 36-42.

4. Bradley BT, Maioli H, Johnston R, Chaudhry I, Fink SL, XU H, Najafian B, Deutsch G, Lacy JM, Williams T, Yarid N, Marshall A. Histopathology and ultrastructural findings of fatal COVID-19 infections in Washington State: a case series. Lancet 2020; 396: 320-332.

5. Chaudhury SS, Sinha K, Majumder R, Biswas A, Mukhopadhyay CD. COVID-19 and central nervous system interplay: A big picture beyond clinical manifestation. J Biosci 2021; 46: 47.
6. Collantes MEV, Espiritu Al, Sy MCC, Anlacan VMM, Jamora RDG. Neurological manifestations in COVID-19 infection: a systematic review and meta-analysis. Can J Neurol Sci 2021; 48: 66-76.

7. Deshaies JE, Shkreta L, Moszczynski AJ, Sidibe’H, Semmler S, Fouillen Al, Bennett ER Bekenstein U, Destroismaisons L, Toutant J, Delmotte Q, Volkening DK, Stabile S, Aulas A, Khalfallah Y, Hermona Soreq H, Nanci A, Strong MJ, Chabot B, Velde CV. TDP-43 regulates the alternative splicing of hnRNP A1 to yield an aggregation-prone variant in amyotrophic lateral sclerosis. Brain 2018; 141: 1320-1333.

8. Dittmayer C, Meinhardt J, Radbruch H, Radke J, Heppner BI, Stenzel W, Holland G, Lause M. Why misinterpretation of electron micrographs in SARS-CoV-2 infected tissue goes viral. Lancet 2020; 396: e64-e65.

9. Dolatshahi M, Sabahi M, Aarabi MH. Pathophysiological clues to how the emergent SARS-CoV-2 can potentially increase the susceptibility to neurodegeneration. Mol Neurobiol 2021; 1: 1-16.

10. Feng W, Zong W, Wang F, Ju S. Severe acute respiratory syndrome coronavirus 2 (SARS-CoV-2): a review. Mol Cancer 2020; 1: 100.

11. Filho AJMC, Gonçalves F, Mottin M, Andrade CH, Fonseca SNS, Macedo DS. Repurposing of tetracyclines for COVID-19 neurological and neuropsychiatric manifestations: a valid option to control SARS-CoV-2- associated neuroinflammation? I Neuroimmune Pharmacol 2021; 16: 213-218.

12. Guerrero JI, Barragán LA, Martínez JD, Montoya JP, Peña A, Sobrino FE, Tovar-Spinoza Z, Ghotme KA. Central and peripheral nervous system involvement by COVID-19: a systematic review of the pathophysiology, clinical manifestations, neuropathology, neuroimaging, electrophysiology, and cerebrospinal fluid findings. BMC Infect Dis 2021; 21: 515.

13. Hikmet F, Méar L, Edvisson A, Micke P, Uhlén M, Lindskog C. The protein expression profile of ACE2 in human tissue. Mol Syst Biol 2020; 16: e9610.

14. Jessen NA, Finmann Munk AS, Lundgaard I, Nedergaard M. The Glymphatic System - a beginner's guide. Neurochem Res 2015; 40: 2583-2599.

15. Kirschenbaum D, Imbach LL, Rushing EJ, Frauenknecht KBM, Gascho D, Ineichen BV, Keller E, Kohler S, Lichtblau M, Reimann RR, Schreib K, Ulrich S, Steiger P, Aguzzi A, Frontzek K. Intracerebral endotheliitis and microbleeds are neuropathological of COVID-19. Neuropathol Appl Neurobiol 2021; 47: 454459.

16. Kuo CL, Pilling LC, Atkins JL, Masoli JA, Delgado J, Kuchel GA, Melzer D. APOE e4 genotype predicts severe COVID-19 in the UK Biobank Community Cohort. I Gerontol A Biol Sci Med Sci 2020; 75: 2231-2232.

17. Lavi E, Cong L. Type I astrocytes and microglia induce a cytokine response in an encephalitic murine coronavirus infection. Exp Mol Pathol 2020; 115: 104474

18. Matschke J, Lütgehetmann M, Hagel C, Sperhake JP, Schröder AS, Edler C, Mushumba H, Fitzek A, Allweiss L, Dandri M, Dottermusch M, Heinemann A, Pfefferle S, Schwabenland M, Magruder DS, Bonn S, Prinz M, Gerloff C, Krasemann S, Aepfelbacher M, Glatzel M. Neuropathology of patients with COVID-19 in Germany: a post-mortem case series. Lancet Neurol 2020; 19: 919-929.

19. Miller SE, Bradley JK. Visualizatio of putative coronavirus in kidney. Kidney Int 2020; 98: 231-232. 
20. Morgello S. Coronaviruses and the central nervous system. J Neurovirol 2020; 26: 459-473.

21. Nailwal H, Chan FK. Necroptosis in antiviral inflammation. Nature 2019; 26: 4-13.

22. Pajo AT, Espiritu Al, Apor ADAO, Jamora RDG. Neuropathologic findings of patients with COVID-19: a systematic review. Neurol Sci 2021; 42: 1255-1266.

23. Reichard RR, Kashani KB, Boire NA, Constantopoulos E, Guo Y, Lucchinetti CF. Neuropathology of COVID-19: a spectrum of vascular and acute disseminated encephalomyelitis (ADEM)like pathology. Acta Neuropathol 2020; 140: 1-6.

24. Sieracka J, Sieracki P, Kozera G, Szurowska E, Gulczyński J, Sobolewski P, Kloc W, Iżycka-Świeszewska E. COVID-19 - neuropathological point of view, pathobiology, and dilemmas after the first year of the pandemic struggle. Folia Neuropathol 2021; 59: 1-16.

25. Tavassoly O, Safavi F, Tavassoly I. Seeding brain protein aggregation by SARS-CoV-2 as a possible long-term complication of COVID-19 infection. ACS Chem Neurosci 2020; 11: 3704-3706.

26. Taylor FB Jr, Kinasewitz GT. The diagnosis and management of disseminated intravascular coagulation. Curr Hematol Rep 2002; 1: 34-40

27. Tetz G, Tetz V. SARS-CoV-2 prion-like domains in spike proteins enable higher affinity to ACE2. http://www.preprints.org (2020). doi: 10.20944/prereprints202003.0422.v1.

28. Tremblay ME, Madore C, Bordeleau M, Tian L, Verkhratsky A Neuropathology of COVID-19: The role for glia. Front Cell Neurosci 2020; 14: 592214.

29. Upadhyay J, Tiwari N, Ansari MN. Role of inflammatory markers in corona virus disease (COVID-19) patients: a review. Exp Bio Med 2020; 245: 1368-1375.

30. Wang D, Hu B, Hu C, Zhu F, Liu X, Zhang J, Wang B, Xiang H, Cheng Z, Xiong Y, Zhao Y, Li Y, Wang X, Peng Z. Clinical characteristics of 138 hospitalized patients with 2019 novel coronavirus-infected pneumonia in Wuhan, China. JAMA 2020; 323 1061-1069.

31. Warraich ST, Yang S, Nicholson GA, Blair IP. TDP-43: A DNA and RNA binding_protein with roles in neurodegenerative diseases. Int J Biochem Cell Biol 2010; 42: 1606-1609.

32. Young MJ, O'Hare M, Matiello M, Schmahmann JD. CreutzfeldtJakob disease in a man with COVID-19: SARS-CoV-2-accelerated neurodegeneration? Brain Behav Immun 2020; 89: 601-603. 